\title{
Front Matter: Volume 9760
}

, "Front Matter: Volume 9760," Proc. SPIE 9760, MOEMS and Miniaturized Systems XV, 976001 (18 August 2016); doi: 10.1117/12.2240460

SPIE. Event: SPIE OPTO, 2016, San Francisco, California, United States 


\title{
PROCEEDINGS OF SPIE
}

\section{MOEMS and Miniaturized Systems XV}

\author{
Wibool Piyawattanametha \\ Yong-Hwa Park \\ Editors
}

\section{5-17 February 2016}

San Francisco, California, United States

Sponsored by

SPIE

Cosponsored by

Samsung Advanced Institute of Technology (Korea, Republic of)

Published by

SPIE 
The papers in this volume were part of the technical conference cited on the cover and title page. Papers were selected and subject to review by the editors and conference program committee. Some conference presentations may not be available for publication. Additional papers and presentation recordings may be available online in the SPIE Digital Library at SPIEDigitallibrary.org.

The papers reflect the work and thoughts of the authors and are published herein as submitted. The publisher is not responsible for the validity of the information or for any outcomes resulting from reliance thereon.

Please use the following format to cite material from these proceedings:

Author(s), "Title of Paper," in MOEMS and Miniaturized Systems $X V$, edited by Wibool Piyawattanametha, Yong-Hwa Park, Proceedings of SPIE Vol. 9760 (SPIE, Bellingham, WA, 2016) Sixdigit Article CID Number.

ISSN: 0277-786X

ISSN: 1996-756X (electronic)

ISBN: 9781628419955

Published by

SPIE

P.O. Box 10, Bellingham, Washington 98227-0010 USA

Telephone +1 3606763290 (Pacific Time) · Fax +1 3606471445

SPIE.org

Copyright @ 2016 , Society of Photo-Optical Instrumentation Engineers.

Copying of material in this book for internal or personal use, or for the internal or personal use of specific clients, beyond the fair use provisions granted by the U.S. Copyright Law is authorized by SPIE subject to payment of copying fees. The Transactional Reporting Service base fee for this volume is $\$ 18.00$ per article (or portion thereof), which should be paid directly to the Copyright Clearance Center (CCC), 222 Rosewood Drive, Danvers, MA 01923. Payment may also be made electronically through CCC Online at copyright.com. Other copying for republication, resale, advertising or promotion, or any form of systematic or multiple reproduction of any material in this book is prohibited except with permission in writing from the publisher. The CCC fee code is 0277-786X/16/\$18.00.

Printed in the United States of America.

Publication of record for individual papers is online in the SPIE Digital Library.

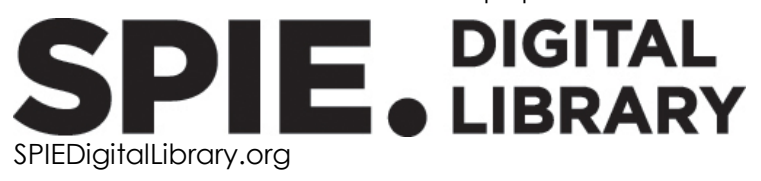

Paper Numbering: Proceedings of SPIE follow an e-First publication model. A unique citation identifier (CID) number is assigned to each article at the time of publication. Utilization of CIDs allows articles to be fully citable as soon as they are published online, and connects the same identifier to all online and print versions of the publication. SPIE uses a six-digit CID article numbering system structured as follows:

- The first four digits correspond to the SPIE volume number.

- The last two digits indicate publication order within the volume using a Base 36 numbering system employing both numerals and letters. These two-number sets start with 00, 01, 02, 03, 04, $05,06,07,08,09,0 A, 0 B \ldots$. OZ, followed by 10-1Z, 20-2Z, etc. The CID Number appears on each page of the manuscript. 


\title{
Contents
}

\author{
$\vee \quad$ Authors \\ vii Conference Committee
}

SESSION 1 MINIATURE INSTRUMENTS FOR ENDOSCOPIC MICROSCOPY: JOINT SESSION WITH CONFERENCES 9691 A AND 9760

976002 A microfabricated water-immersible scanning mirror with a small form factor for handheld ultrasound and photoacoustic microscopy [9760-1]

976003 A two-axis water-immersible MEMS scanning mirror for scanning optical and acoustic microscopy [9760-2]

SESSION 2 SPATIAL LIGHT MODULATOR TECHNOLOGIES FOR 3D APPLICATIONS: JOINT SESSION WITH CONFERENCES 9760 AND 9761

976004 Wearable and augmented reality displays using MEMS and SLMs (Invited Paper) [9760-3]

\section{SESSION 3 MICROSCANNER}

976006 MEMS-mirror based trajectory resolution and precision enabled by two different piezoresistive sensor technologies (Invited Paper) [9760-5]

$976008 \quad$ Modeling of biaxial gimbal-less MEMS scanning mirrors [9760-7]

976009 Real-time closed-loop control for micro mirrors with quasistatic comb drives [9760-8]

\section{SESSION $4 \quad$ MOEMS COMPONENTS AND SYSTEMS}

9760 OD Mechanically flexible waveguide arrays for optical chip-to-chip coupling [9760-14]

9760 OE Mechanically tunable photonic crystal split-beam nanocavity (Best Student Paper Award) [9760-15]

\section{SESSION $5 \quad$ MICROSPECTROMETER AND OPTICAL FILTERS}

$9760 \mathrm{OH} \quad$ Tunable MEMS Fabry-Pérot filters for infrared microspectrometers: a review (Invited Paper) [9760-18] 
97600 Ol VIS Fabry-Pérot-Interferometer with $(\mathrm{HL})^{4} \mathrm{PE}-\mathrm{Si}_{3} \mathrm{~N}_{4} / \mathrm{PE}-\mathrm{SiO}_{2}$ reflectors on freestanding $\mathrm{LP}-\mathrm{Si}_{3} \mathrm{~N}_{4}$ membranes for surface enhanced Raman spectroscopy [9760-19]

9760 0J Deeply etched micromirror with vertical slit and metallic coating enabling transmissiontype optical MEMS filters [9760-20]

9760 OK Mid infrared MEMS FTIR spectrometer [9760-21]

$9760 \mathrm{OL} \quad$ Novel Fourier transform infrared spectrometer architecture based on cascaded FabryPerot interferometers [9760-22]

9760 OM MOEMS FPI sensors for NIR-MIR microspectrometer applications [9760-23]

\section{SESSION $6 \quad$ MOEMS FOR SENSING AND IMAGING APPLICATIONS I}

9760 ON Ultra-slim 2D- and depth-imaging camera modules for mobile imaging (Invited Paper, Best Paper Award) [9760-24]

9760 OP Study on sputtered a-Si:H for micro optical diffusion sensor using laser-induced dielectrophoresis [9760-26]

$97600 Q \quad$ Low power and highly precise closed-loop driving circuits for piezoelectric micromirrors with embedded capacitive position sensors [9760-27]

\section{SESSION 7 MOEMS FOR SENSING AND IMAGING APPLICATIONS II}

9760 OS Novel multi-aperture approach for miniaturized imaging systems [9760-29]

9760 OU Miniature electrically tunable rotary dual-focus lenses [9760-31]

9760 OV NEMS-based MIM plasmonics tunable filter [9760-32]

9760 OW Transition of optical regime in miniaturized optical systems: light interactions beyond the refraction limit [9760-35]

POSTER SESSION

9760 OX Optically pumped 1550nm wavelength tunable MEMS VCSEL [9760-17]

9760 OY Analyzing effects of aperture size and applied voltage on the response time [9760-33] 


\section{Authors}

Numbers in the index correspond to the last two digits of the six-digit citation identifier (CID) article numbering system used in Proceedings of SPIE. The first four digits reflect the volume number. Base 36 numbering is employed for the last two digits and indicates the order of articles within the volume. Numbers start with $00,01,02,03,04,05,06,07,08,09,0 A, 0 B . .0 Z$, followed by 10-1Z, 20-2Z, etc.

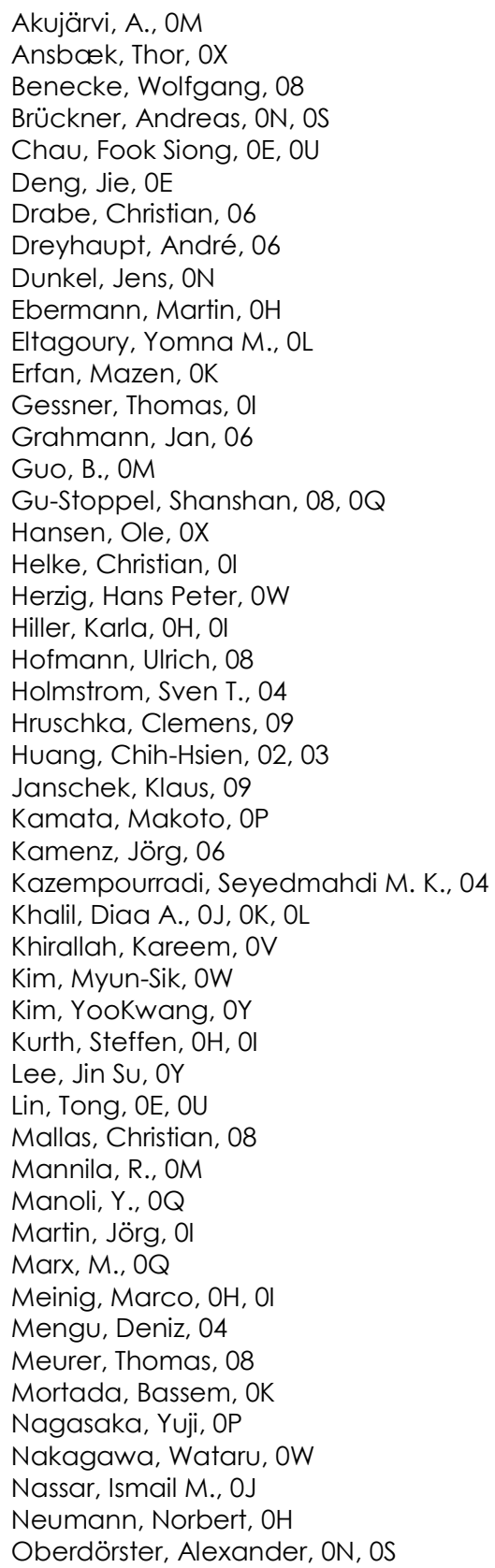

Olcer, Selim, 04

Othman, Muhammad A., OJ

Ottaviano, Luisa, OX

Peters, Tjitte-Jelte, OD

Reimann, Andreas, ON, OS

Rissanen, A., OM

Rockstuhl, Carsten, OW

Rombach, S., $0 Q$

Roth, Matthias, 09

Sabry, Yasser M., OJ, OK, OL

Sadek, Mohamed, OJ

Sahoo, Hitesh K., OX

Sandner, Thilo, 06, 09

Scharf, Toralf, OW

Schrödter, Richard, 06, 09

Seifert, Mario, $\mathrm{OH}, \mathrm{Ol}$

Seiler, Jan, Ol

Semenova, Elizaveta S., OX

Senger, Frank, 08

Sharaf, Khaled, OK

Swillam, Mohamed A., OV

Taguchi, Yoshihiro, OP

Tichem, Marcel, OD

Ulusoy, Erdem, 04

Urey, Hakan, 04

Voelkel, Reinhard, OW

von Wantoch, Thomas, 08

Wippermann, Frank, ON, OS

Won, Yong Hyub, OY

$\mathrm{Xu}$, Song, 02, 03

Yamada, Kan, OP

Yvind, Kresten, OX

Zhang, Wei, OU

Zhou, Guangya, OE, OU

Zou, Jun, 02, 03

Zou, Yongchao, OE, OU 
Proc. of SPIE Vol. $9760976001-6$

Downloaded From: https://www.spiedigitallibrary.org/conference-proceedings-of-spie on 26 Apr 2023 Terms of Use: https://www.spiedigitallibrary.org/terms-of-use 


\title{
Conference Committee
}

\author{
Symposium Chairs
}

Jean-Emmanuel Broquin, IMEP-LAHC (France)

Shibin Jiang, AdValue Photonics, Inc. (United States)

Symposium Co-chairs

David L. Andrews, University of East Anglia (United Kingdom)

Alexei L. Glebov, OptiGrate Corporation (United States)

2016 Program Track Chairs

Holger Becker, microfluidic ChipShop GmbH (Germany)

Winston V. Schoenfeld, CREOL, The College of Optics and Photonics,

University of Central Florida (United States)

Conference Chairs

Wibool Piyawattanametha, KMITL (Thailand) and Chulalongkorn University (Thailand)

Yong-Hwa Park, Samsung Advanced Institute of Technology

(Korea, Republic of)

Conference Program Committee

Wyatt O. Davis, MicroVision, Inc. (United States)

David L. Dickensheets, Montana State University (United States)

Jean-Christophe Eloy, Yole Développement (France)

Jan Grahmann, Fraunhofer-Institut für Photonische Mikrosysteme (Germany)

Jason C. Heikenfeld, University of Cincinnati (United States)

Ulrich Hofmann, Fraunhofer-Institut für Siliziumtechnologie (Germany)

II-Woong Jung, Argonne National Laboratory (United States)

David G. Lishan, Plasma-Therm LLC (United States)

Jonathan T. Liu, Stony Brook University (United States)

Veljko Milanovic, Mirrorcle Technologies, Inc. (United States)

Harald Schenk, Fraunhofer-Institut für Photonische Mikrosysteme

(Germany)

Jason B. Stewart, MIT Lincoln Laboratory (United States)

Wanjun Wang, Louisiana State University (United States)

Guangya Zhou, National University of Singapore (Singapore) 
Session Chairs

1 Miniature Instruments for Endoscopic Microscopy: Joint Session with Conferences $9691 \mathrm{~A}$ and 9760

Wibool Piyawattanametha, KMITL (Thailand) and Chulalongkorn University (Thailand)

2 Spatial Light Modulator Technologies for 3D Applications: Joint Session with Conferences 9760 and 9761

Benjamin L. Lee, Texas Instruments Inc. (United States)

Badia Koudsi, Optecks, LLC (United States)

3 Microscanner

Yong-Hwa Park, Samsung Advanced Institute of Technology (Korea, Republic of)

4 MOEMS Components and Systems

Jan Grahmann, Fraunhofer-Institut für Photonische Mikrosysteme (Germany)

5 Microspectrometer and Optical Filters

David G. Lishan, Plasma-Therm LLC (United States)

6 MOEMS for Sensing and Imaging Applications I

Ulrich Hofmann, Fraunhofer-Institut für Siliziumtechnologie (Germany)

7 MOEMS for Sensing and Imaging Applications II

Guangya Zhou, National University of Singapore (Singapore) 